\title{
Perianal Methylene Blue Injection in Patient With Pruritus Ani Unresponsive To Medical Treatment: Video Presentation
}

\section{Medikal Tedaviye Yanıtsız Pruritus Ani'li Hastada Perianal Metilen Mavisi Enjeksiyonu: Video Prezentasyon}

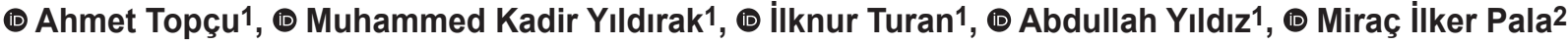 \\ 1 University of Health Sciences Turkey, Ümraniye Training and Research Hospital, Clinic of General Surgery, İstanbul, Turkey \\ 2istanbul Medipol University Faculty of Medicine, Department of General Surgery, İstanbul, Turkey
}

\section{HIIIIII| ABSTRACT}

Pruritus Ani is one of the common dermatological diseases of the perianal skin in the general population. This disease affects $1 \%-5 \%$ of the society. It presents as itching and burning in the perianal area. Men are affected four times more than women, and it is diagnosed most commonly in the fourth to sixth decades of life. This disease, which is most commonly seen as idiopathic, may develop secondary to infectious factors such as staph. aureus, candida albicans, thinning of the perianal skin due to the long-time use of topical steroids, dermatological diseases such as psoriasis or malignancies. The treatment of the underlying disease constitutes the main treatment for the secondary disease, and in the idiopathic disease, a wide range of treatment methods are used, from conservative treatments to various medical treatments and injection of various substances into the perianal area. In this video presentation, it is aimed to present the application of methylene blue injection to the perianal skin in a patient with idiopathic pruritus ani unresponsive to medical treatment.

Keywords: Methylene blue injection, perianal itching, pruritus ani

\section{|IIIIIIII| ÖZ}

Pruritus ani toplumda sık karşılaşılan perianal bölgenin dermatolojik hastalıklarındandır. Bu hastalık toplumun \%1-\%5'ini etkilemektedir. Perianal bölgede kaşıntı ve yanma olarak prezente olur. Erkeklerde kadınlara oranla dört kat fazla görülür ve en sık görülme yaşı dördüncü ve altıncı dekatlar arasındadır. En sık idiopatik olarak görülen bu hastalık staf. aureus, candida albicans gibi enfeksiyöz etkenlere, uzun süre steroidli topikal ajanların kullanımına bağlı perianal bölge cildinin incelmesine, psoriasis gibi dermatolojik hastalıklara veya malignitelere sekonder olarak gelişebilmektedir. Sekonder hastalıkta altta yatan hastalığın tedavisi esas tedaviyi teşkil etmekte olup idiopatik hastalıkta ise konservatif tedavilerden çeşitli medikal tedavilere ve çeşitli maddelerin perianal bölgeye enjeksiyonuna kadar geniş bir yelpazede bir çok tedavi yöntemi uygulanmaktadır. Bu video prezentasyonda medikal tedaviye yantısız idiopatik pruritus anili bir hastada perianal bölgeye metilen mavisi enjeksiyonu uygulamasının sunulması amaçlanmıştır.

Anahtar Kelimeler: Metilen mavisi enjeksiyonu, perianal kaşıntı, pruritus ani

\section{Introduction}

Pruritus ani is one of the most common diseases among benign anorectal disease group encountered in the society. The men/women incidence of this disease which affects one out of every twenty people in the society is $4 .{ }^{1}$ Various factors such as personal hygiene, obesity, wearing tight clothing and psychogenic causes play a role in the etiology of idiopathic pruritus ani. Skin biopsy should be done first for diagnosis.

Address for Correspondence/Yazıșma Adresi: Muhammed Kadir Yıldırak, MD 
After the secondary causes are ruled out, the initial treatment should be administered to the patient for 2-4 weeks. In this treatment, first of all, topical irritants (stool contamination, soap, perfume, etc.) should be eliminated and excessive anal hygiene habits should be avoided. The consumption of food products such as coffee, soda and alcohol should be reduced. Afterwards, topical steroids and oral antipruritic agents should be used in decreasing doses for 4-8 weeks. A method that has been used with increasing frequency recently is methylene blue injection into the perianal skin. In this method, $8 \mathrm{ml}$ of $2 \%$ methylene blue is mixed with $0.5 \%$ lidocaine in the same volume and injected into the perianal dermis with a 22 gauge needle and it has been shown that the possibility of complications such as skin necrosis is low, when the method is applied correctly. ${ }^{2}$ In this video presentation, a patient with pruritus ani, who was unresponsive to medical treatment, was administered methylene blue injection treatment with the described technique.

No preoperative preparation was made for the patient. Prophylactic antibiotherapy or enema was not applied in the preoperative period. The patient underwent surgery in the prone jack-knife position. Eight cc of $2 \%$ methylene blue was mixed with 8 cc $0.5 \%$ lidocaine and injected intradermally to the entire perianal area using a 22 gauge needle and the procedure was terminated.

In conclusion, we think that in patients with pruritus ani refractory to conservative treatment, injection of methylene blue into the perianal region is a cheap, easy-to-apply and satisfying method for patients.

* This video presentation was recorded at the proctology course held at University of Health Sciences Turkey, Ümraniye Training and Research Hospital on 17.10.2020.

Informed Consent: Obtained.

Peer-review: Externally and internally peer reviewed.

\section{Authorship Contributions}

Surgical and Medical Practices: MK.Y., M.F.P., Concept: M.K.Y., Design: F.T., A.Y., Data Collection or Processing: F.T., Analysis or Interpretation: M.K.Y., M.F.P., Literature Search: M.K.Y. A.T., Writing: M.K.Y., A.T.

Conflict of Interest: No conflict of interest was declared by the authors.

Financial Disclosure: The authors declared that this study received no financial support.

\section{References}

1. Steele SR, Hull TL, Read TR, Saclarides TJ, Senagore AJ and Whitlow CB. The ASCRS Textbook of Colon and Rectal Surgery, 3th ed. Arlington Heights, IL, USA: Springer; 2016;243-259.

2. Menteş B, Bulut MT, Alabaz Ö ve Leventoğlu S. Anorektal Bölgenin Selim Hastalıklanı, Türk Kolon ve Rektum Cerrahisi Derneği, İstanbul, Türkiye 2011;133-145.

Video 2.

https://www.doi.org/10.4274/tjcd.galenos.2020.2020-11-2.video2 